\title{
DOES THE PREVENTION OF ILLEGAL EVICTION FROM AND UNLAWFUL OCCUPATION OF LAND ACT OF 1998 PROVIDE ADEQUATE FAMILY HOME PROTECTION TO INSOLVENT DEBTORS OR IS IT STILL PIE IN THE SKY? (PART 2)
}

\author{
André Boraine \\ Blur LLB LLM LLD \\ Faculty of Law, University of Pretoria
}

\section{SUMMARY}

Although some legal systems provide some protection for a debtor's homestead or family home when his or her estate is insolvent, such direct protective measures are absent in South African insolvency law. Such protection during insolvency can be provided by means of some level of exemption for the insolvent's family home or homestead, as in the insolvency laws of the USA, or by providing protection of occupancy to the insolvents and his or her dependants, as is the case in England and Wales.

In view of developments concerning the protection of a debtor's primary residence in South African individual debt collecting and execution procedures (in light of the right to housing provided for in section 26 of the Constitution), the question was posed in Part 1 of this article whether a court hearing an application for compulsory sequestration should apply the same principles, especially if the debtor raises the point that the sequestration order may render him or her homeless. In this respect, no direct authority for this proposition could be found. (Commentators have argued for some time that the position of the homestead of the debtor in insolvency needs the legislature's attention as well, but there has not been real progress in this regard to date.)

However, there are a few judgments in which courts have considered the applicability of the Prevention of Illegal Eviction From and Unlawful Occupation of Land Act 19 of 1998 (the PIE Act) after sequestration of the insolvent's estate. Part 2 of the article is therefore devoted to discussing developments in this regard and to considering what problems are encountered in applying the PIE Act during a debtor's insolvency. Part 2 also considers whether this Act provides sufficient protection to insolvent debtors to prevent them from being evicted from "their" homes when they cannot afford alternative accommodation.

Against this background, the two parts of the article deal with different aspects of the issue under discussion. Ultimately, the two parts aim to provide some answers to

See Boraine "Does the Prevention of Illegal Eviction From and Unlawful Occupation of Land Act of 1998 Provide Adequate Family Home Protection to Insolvent Debtors or Is It Still Pie in the Sky? (Part 1)" 202041 Obiter 199-225. 
the pertinent question - that is, whether the PIE Act can provide effective interim and/or adequate protection to an insolvent debtor who may be evicted from his or her (former) homestead, in particular in the absence of direct measures in insolvency law to protect insolvents and their dependants under these circumstances. In raising this question, pertinent issues regarding the application of the PIE Act in insolvency are also considered.

\section{THE ESSENTIALS OF THE PIE ACT}

\section{Overview}

The Prevention of Illegal Eviction From and Unlawful Occupation of Land Act 19 of 1998 (PIE Act) came into force on 5 June $1998 .{ }^{2}$ It is clear the Act was inspired by section 26 of the Constitution of the Republic of South Africa, 1996 (Constitution) as in terms of its long title its aims are to provide for the prohibition of unlawful eviction and procedures for the eviction of unlawful occupiers. $^{3}$ Examples of unlawful occupiers include a person who trespassed on land and established a shelter there (a typical squatter scenario), a former tenant of a terminated or expired lease agreement, or a mortgagor holding over on a property sold or bound to be sold in execution. ${ }^{4}$ Among other aims, and in terms of its Preamble, the PIE Act broadly intends to assist in ensuring that no person is deprived of property except in terms of a law of general application and to prevent arbitrary deprivation of property in terms of any law. In particular, it states that no one may be evicted from their home, or have their home demolished without an order of court made after considering all the relevant circumstances. To this end, the Act states that it is desirable that the law should regulate the eviction of unlawful occupiers from land in a fair manner, while recognising the right of landowners to apply to a court for an eviction order in appropriate circumstances. It is notable that section 4(1) makes it clear that this Act trumps the common law or any law relating to eviction. ${ }^{5}$ Also, it is clear the Act may avail an insolvent debtor after sequestration of his or her estate if all

2 The PIE Act assists in giving effect to socio-economic rights relating to the right to housing and has its roots, inter alia, in s 26(3) of the Bill of Rights, which provides that "no one may be evicted from their home without an order of court made after consideration of all the relevant circumstances" (Cape Killarney Property Investment (Pty) Ltd v Mahamba 2001 (4) SA 1222 (SCA) 1229E). The PIE Act invests in the courts the right and duty to make the order that, in the circumstances of the case, would be just and equitable, and it prescribes some circumstances that have to be taken into account in determining the terms of the eviction.

3 See Smith Eviction and Rental Claims: A Practical Guide (2013) ch 3; Pienaar Land Reform (2014) ch 10; and Muller, Brits, Pienaar and Boggenpoel Silberberg: The Law of Property 6ed (2019) 751 for comprehensive discussions of the PIE Act. This article however focuses on those sections of the Act that are relevant to the application of the PIE Act in insolvency.

$4 \quad$ Ndlovu v Ngcobo 2003 (1) SA 113 (SCA); see Pienaar Land Reform 703 ff, where she refers to earlier proposed amendments to exclude the PIE Act's application to the latter two categories.

5 The wording of the section states: "[n]otwithstanding anything to the contrary contained in any law or the common law, the provisions of this section apply to proceedings by an owner or person in charge of land for the eviction of an unlawful occupier." 
the requirements are met, although the PIE Act does not refer to sequestration as such. ${ }^{6}$

In an eviction application, the court considers the rights of the owner as well as the unlawful occupier. It is of major importance that special consideration be given to the rights of the elderly, children, disabled persons and particularly households headed by women, and it should be recognised that the needs of those groups should be considered in a case of eviction. ${ }^{7}$

The operation of the Act is not restricted as to its application to an insolvent's estate after sequestration since the Act prescribes no bar on its application in this respect. ${ }^{8}$ When applied in a sequestration situation, pertinent questions arise relating to whether the trustee has locus standi to bring the application, and under what circumstances the insolvent will be deemed to occupy the property unlawfully.

For the purposes of this article, certain definitions in section 1 of the PIE Act are of importance.

First, the definition of "unlawful occupier" is key and refers to a person who occupies land without the explicit or tacit consent of the owner or person in charge or without any other right in law to occupy such land. This definition does not refer only to the owner of land but refers to any person who occupies land unlawfully, which may of course be the (registered) owner or any other occupant. Also, it is important to note that the definition refers to the explicit or tacit consent of the owner or the person in charge. ${ }^{9}$

After this Act came into operation, the courts grappled with the question (among others) whether the Act included only persons like squatters who occupied land unlawfully - without the consent of the owner - or whether it also referred to persons who at some stage occupied the property legally, such as the owner or a tenant of property, but whose occupation at a later stage became illegal. In Ndlovu $v$ Ngcobo, ${ }^{10}$ the majority judgment of the Supreme Court of Appeal ruled that the definition would include both categories of occupiers, but at the time of the application for eviction the occupation must have been unlawful. Within the insolvency context therefore, it is important for the applicant to first establish that occupation of the family home is unlawful at the time when he or she seeks eviction.

Read with the Preamble, which states that no one may be evicted from their home without an order of court made after considering all the relevant circumstances, the definition of "building or structure" is very important since it includes any hut, shack, tent or similar structure or any other form of

6 The purpose of this article is not to provide a comprehensive discussion of the PIE Act but is to highlight those aspects pertinent to the eviction of an occupier of land for residential purposes - especially insofar as they relate or may relate to the insolvency of the home owner or occupant.

7 S 4(7) of the PIE Act.

8 See par 7 of this article for a discussion of cases where the Act featured in the postsequestration phase of insolvency.

9 The facts of course determine if such consent was granted or not. See, in general, Residents of Joe Slovo Community v Thubelisa Homes 2010 (3) SA 454 (CC) for issues relating to consent in cases of state-owned land as discussed by Muller et al Silberberg 752.

10 Supra. 
temporary or permanent dwelling or shelter. It is clear from this definition that an ordinary house or apartment of an insolvent debtor falls under the definition. But, this definition is broad enough to include other types of abode that he or she may use as a dwelling or shelter - such as a caravan, a shipping container or even a sheet of plastic or canvas. Cases may emerge where a person occupies bare land for residential purposes. In view of this possibility, the question may well be asked if the PIE Act also applies where the insolvent and his or her dependants occupy the insolvent's holiday apartment, caravan and/or camping tent as their home after they have vacated the primary residence. In terms of the definition, these "structures" seem to fall under the definition, but it must be noted that the Act refers to unlawful occupancy of land whereas the definition of eviction, as referred to below, refers to eviction from occupation of a building or structure or the land. It is submitted that it is important to read this definition in conjunction with the Preamble, which states that no one may be evicted from their home without a court order and after considering all the facts. However, it seems that courts may scrutinise the type of dwelling with a view to establishing whether it is the primary residence of the occupant or if the structure is intended for human dwelling or shelter; if not, the court may well come to the conclusion that the protective measures of the Act do not apply. ${ }^{11}$

Smith argues that the PIE Act concerns not only land on which buildings are erected but includes all land of a residential nature. In order to ascertain the property (home) to which the PIE Act applies, ${ }^{12}$ he refers to the different terms used in the Act in this context; for instance, the Preamble refers to persons being "evicted" from their homes, whereas other parts of the Preamble refer to people being deprived of "property". The PIE Act also states that the law should "regulate the eviction of unlawful occupiers from land". He submits that "property" and "land" should not be interpreted restrictively and, for instance, a holiday home could, depending on the circumstances, be included. In support of a more flexible interpretation, he refers to section 25(4)(b) of the Constitution, where property is described as "not limited to land" and to the use of the words "temporary" and "form of dwelling" in the definition of "building or structure" in s 1 of the PIE Act. In the same vein, Muller et al concludes:

"[w]hile the essential jurisdictional elements had been identified as the unlawful occupation of homes, dwellings and abodes, courts still struggle to ascertain the elements in practice. The result is that some courts continue to grant eviction orders outside the paradigm that was specifically developed to give effect to constitutional imperatives. This cannot continue. Once unlawful

11 See Barnett $v$ Minister of Land Affairs 2007(6) SA 328B-C, where the court ruled that the Act, for instance, will not cover holiday homes. In this regard, the court appreciated that a person may have more than one residence and it was mindful of the reference in the Preamble to "home" read with s 26(3) of the Constitution, but it found that the term "home" implied an element of regular occupation linked with some degree of permanence (see 327-328). See Ndlovu v Ngcobo supra 124H-125A and Shoprite Checkers Ltd v Jardim 2004 (1) SA 502 (O).

12 The purpose of this article, however, is not to provide a comprehensive discussion of the PIE Act but those aspects pertinent to the eviction of an occupier of land for residential purposes are discussed - especially insofar as they relate or may relate to insolvency of the home owner or occupant. 
occupation had been established, and it is clear that the relevant property embodies housing or shelter, the PIE Act has to be employed." ${ }^{13}$

It is submitted that the use of the structure is of paramount importance and if used for dwelling or shelter purposes as a home of the occupant - even when deemed to be movable - it should be subject to the eviction procedure of the PIE Act. This aspect must be read with the definition of "evict", which means to deprive a person of occupation of a building or structure, or the land on which such building or structure is erected, against his or her will and "eviction" has a corresponding meaning. These aspects read together, it seems, mean that eviction may relate to the occupancy of land where the occupier occupies a structure permanently erected on such land, or where he or she merely occupies the land as such for purposes of dwelling or shelter, or it may relate to the mere occupancy of a movable structure stationed on land. ${ }^{14}$ In this context, the broad interpretation advocated by Smith and Muller et al is fully endorsed.

In determining whether the occupation of the occupier is lawful, it must be noted that consent to occupy the premises (for temporary or permanent dwelling or shelter purposes) can be granted explicitly or tacitly, in writing or otherwise, by the owner or person in charge of the land in question. As indicated above, the position of the trustee of an insolvent estate differs from that of the sheriff, since the insolvent estate of the insolvent debtor ultimately vests in the trustee. Therefore, it is submitted that continued occupation by the insolvent after sequestration ultimately depends on the decision of the trustee. If an insolvent's occupation of a building or structure that forms part of the estate assets after sequestration is tolerated, it may be interpreted as tacit consent. From a practical point of view, it is submitted that the trustee should make clear whether or not he or she has consented to the insolvent's continued occupation - for instance, by giving notice to vacate to the insolvent or others, such as family members, occupying the residence in order for the property to be realised for the benefit of the creditors. Such a notice may assist in determining if the occupation is (or becomes) unlawful for the purposes of the Act from an evidentiary point of view. But if the trustee allows the insolvent to remain in the house until a later date - the sale date of the property, for instance - the occupation should be taken to be lawful. In practice, the trustee sometimes allows the insolvent to remain in occupation but then attempts to gain a "rental" income from the insolvent. The benefit of such an arrangement is that the property earns income to defray expenses in relation to it and the trustee may save the cost of placing a security guard on the premises to protect it, but (depending on the terms of the arrangement) it may complicate matters when ultimately trying to get the insolvent to vacate the premises.

Since only the owner or an organ of state, as defined in section 239 of the Constitution, has locus standi to evict an occupier of a building or structure, the definition of the term "owner" is important. The definition includes the registered owner of land and an organ of state. The "person in charge"

3 Muller et al Silberberg 753.

14 To "evict" an occupier means to deprive a person of occupation of a building or structure, or the land on which such building or structure is erected, against his or her will, and "eviction" has a corresponding meaning. 
means a person (not necessarily the owner) who has (or, at the relevant time, had) legal authority to give a person permission to enter or reside upon the land in question. ${ }^{15}$ It is submitted that the trustee in an insolvent estate should be deemed to be the registered owner of immovable property in the insolvent's estate although the title deed of the immovable property will not be registered in his or her name. In this regard, section 20(1) of the Insolvency Act $^{16}$ (the section that vests the estate property in the trustee) must be read with the definition of "owner" in section 102 of the Deeds Registry Act, ${ }^{17}$ where this definition includes the trustee. ${ }^{18}$ Section 58 of the Deeds Registry Act requires the trustee to transfer immovable property back to the insolvent should it re-vest in the insolvent after rehabilitation and only the trustee is entitled to give transfer of such property after sequestration. In any event, should a court find that the trustee cannot be deemed to be the registered owner as defined, the trustee at least qualifies as the person in charge of the property as defined in section 1 of the PIE Act. So, the trustee clearly has locus standi to bring an application for eviction.

An insolvent individual may also have the use and occupation of a residence registered, for instance, in the name of a company, a close corporation or a trust under such insolvent's control. In Van der Merwe NO $v$ Moodliar NO, ${ }^{19}$ the residence occupied by the insolvent vested in a company under liquidation owing to its insolvency. The company used to be under the control of the insolvent before its liquidation. In this case, the liquidators of the company successfully applied for the eviction of the insolvent individual who continued to occupy the premises after liquidation of the company; the judge remarked that the liquidators applied for the eviction of the occupants in order to put them in a position, ultimately, to sell the property unoccupied. ${ }^{20}$ Suffice it to say that, in the Van der Merwe case, the court clearly accepted that the liquidators had locus standi to bring the eviction application in terms of the PIE Act. It is submitted that although the property of a company in liquidation remains vested in the company, the liquidator will be deemed the person in charge of such property; unlike the trustee appointed in terms of the Insolvency Act, the liquidator (upon his or her appointment) merely acquires control of the property. ${ }^{21}$

Section 4(1) of the Act states that, notwithstanding anything to the contrary contained in any law or the common law, the provisions of the section apply to proceedings by an owner or person in charge of land for the eviction of an unlawful occupier. This means that the section must be

See further Smith Eviction and Rental Claims par 3.4; Pienaar Land Reform $717 \mathrm{ff}$.

24 of 1936.

47 of 1937.

18 See the discussion in the previous paragraph regarding the notion of ownership of the insolvent estate property.

19 Van der Merwe NO v Moodliar NO; Van der Merwe NO v Moodliar NO; Nkhoma NO v Moodliar NO [2019] ZAWCHC 160; [2020] 1 All SA 558 (WCC).

20 An important observation at par 33 is the reference to Kuper J, in $S A$ Clay Industries $v$ Katzenellenbogen NO 1957 (1) SA 220 (W) 224, who said that "the whole machinery of the [Companies] Act is directed towards a speedy liquidation and distribution of the assets of an insolvent estate".

21 S 361 of the Companies Act 61 of 1973 provides that, in any winding-up by the court, all the property concerned shall be deemed to be in the custody and under the control of the Master until a provisional liquidator has been appointed and has assumed office. 
complied with in the case of an eviction of an unlawful occupant. Whenever an insolvent's occupancy of the structure that he or she uses for dwelling or shelter purposes can be deemed unlawful, the applicant as defined may apply for his or her eviction. Clearly, in many such instances, spouses, children and or other family members occupy the premises as well. Although the structure used for residential purposes probably will be a house or apartment, and subject to a mortgage bond in the majority of insolvency matters, it must be noted that it may also be a property that does not serve as security or it may be a movable asset of the insolvent such as a caravan, tent or a shipping container as mentioned before. ${ }^{22}$

Section 4 then sets out the process to be followed by the owner or person in charge of the property, being the applicant with locus standi, and prescribes a 14-day notice of the proceedings to be given to the unlawful occupier and the local municipality. The notice, among other matters, states that the unlawful occupier is entitled to appear before the court and defend the case.

It is notable that the local municipality in whose area of jurisdiction the property is situated must be informed as well. The municipality of course is a body that may be able to provide alternative land or housing, but in practice this seems easier said than done owing to a lack of available land or housing. The municipality is also empowered in terms of section 7 of the Act to facilitate mediation between the interested parties to settle any dispute in terms of the Act. In practice, municipalities are not very active in these proceedings, especially when the applicant is a private individual. ${ }^{23}$

On a substantive basis, the court may grant an eviction order where an unlawful occupier has occupied the land in question for less than six months at the time that the proceedings are initiated if it is of the opinion that it is just and equitable to do so and after considering all relevant circumstances, including the rights and needs of the elderly, children, disabled persons and households headed by women.

The relevant circumstances to be considered by the court require a balance between the interests of the owner and the unlawful occupier(s) with a view to finding a "just and equitable" solution. ${ }^{24}$ Relevant circumstances mentioned in section 4(7) are the rights and needs of the elderly, children, disabled persons and households headed by women. It was intended that a court should have broad discretion to look at various relevant factors that may affect the eviction. ${ }^{25}$ Smith indicates that the rights in section 4(7) include the rights to human dignity, the right not to be treated in a cruel,

22 S 1 of the PIE Act; see definition of "building or structure".

23 See in general Pienaar Land Reform 725; and Modderklip Boerdery (Pty) Ltd 2005 (5) SA 3 (CC), which notes that the courts don't treat the constitutional duty of municipalities to provide housing as an absolute right or duty.

24 Smith Eviction and Rental Claims 3-41, where the author discusses various aspects, such as emotional aspects owing to the trauma suffered when the home is lost, and the dignity of the occupants. See also Port Elizabeth Municipality v Various Occupiers 2005 (1) SA 217 (CC) 233F; Davids v Van Straaten 2005 (4) SA 468 (CPD) 484B-D; Arendse v Arendse 2013 (3) SA 347 (WCC); Machele v Mailula 2010 (2) SA 267 (CC). See also Pienaar Land Reform $727 \mathrm{ff}$ for a discussion of the so-called defences that may be raised.

25 See Smith Eviction and Rental Claims 3-41 with reference to ABSA Bank Ltd v Murray 2004 (2) SA 15 (CPD) 26G. 
inhumane or degrading way, the constitutional rights of children and the availability of alternative accommodation in the context of the State's obligation to provide access to land. ${ }^{26}$ Steyn submits that the developments and consideration laid down by the courts in the individual attachment and execution procedures may also be relevant in cases of eviction since there is a clear link between these situations. ${ }^{27}$

Where an unlawful occupier has occupied the land in question for more than six months at the time the proceedings are initiated, a court may grant an order for eviction under similar circumstances to the previous case, (except where the land is sold in a sale of execution pursuant to a mortgage), whether land has been made available or can reasonably be made available by a municipality or other organ of state or another land owner for the relocation of the unlawful occupier and including the rights and needs of the elderly, children, disabled persons and households headed by women. ${ }^{28}$ It is submitted that, for the sake of clarity, the exception could have been drafted more elegantly. In Ndlovu $v$ Ncgobo, this exception regarding a house sold in execution was termed an anomaly and it may well be asked whether the exception in itself does not militate against section 26 of the Constitution. ${ }^{29}$ It is to be noted that the exception refers only to judicial execution following the individual attachment and execution process as described above, since a sale emanating from an insolvent estate is not termed an execution sale in the Insolvency Act. ${ }^{30}$ It seems the thinking was that a person who could afford a mortgage bond should be able to find alternative accommodation, which may of course not always be the case. Pienaar mentions that the notion of alternative accommodation is very important where the occupation of premises has been for longer than six months. ${ }^{31}$ But the courts seem to draw a distinction between privately owned land and public land. In the first-mentioned instance, the availability of alternative accommodation may be more relevant to the date of the eviction order.

Where the court is satisfied that all the requirements of this section have been complied with, and that no valid defence has been raised by the unlawful occupier, it must grant an order for the eviction of the unlawful occupier, and determine:

Smith Eviction and Rental Claims 3-42.

27 See Steyn Statutory Regulation of Forced Sale of the Home in South Africa (doctoral thesis, University of Pretoria) 2012 63, where she points out, with reference to Gundwana v Steko 2011 (3) SA 608 (CC) par 23, 41, 44 and 46 and Government of the Republic of South Africa v Grootboom 2000 (11) BCLR 1169 (CC); 2001 (1) SA 46 (CC) par 34 and subsequent cases, that connections have been made between the forced sale of a debtor's home (in individual attachment and execution) and the eviction of a person from his or her home.

28 S 4(7) of the PIE Act.

29 Ndlovu $v$ Ngcobo supra par 10. It is clear the legislature considered the rights and interests of the mortgagee in this instance and decided that it should be of greater importance than the rights of the insolvent under these circumstances. See also Brodie $v$ Kgomasang unreported case no 32683 of 2019 (GJ) par 28.

3024 of 1936.

31 See Pienaar Land Reform 724, where the author refers to City of Johannesburg $v$ Changing Tides 74 (Pty) Ltd 2012 (6) SA 294 (SCA). 
(a) a just and equitable date on which the unlawful occupier must vacate the land under the circumstances; and

(b) the date on which an eviction order may be carried out if the unlawful occupier has not vacated the land on the date contemplated in paragraph (a)..$^{32}$

Importantly for this discussion, section 4(9) of the PIE Act states that in determining a just and equitable date contemplated in subsection (8), the court must have regard to all relevant factors, including the period the unlawful occupier and his or her family have resided on the land in question. Even where the occupant must vacate the premises, the courts must still provide a just and equitable date for this - clearly with the interests of the occupant in finding alternative accommodation in mind. ${ }^{33}$

A court that orders the eviction of any person in terms of this section may make an order in terms of section 4(10) for the demolition and removal of the buildings or structures that were occupied by such a person on the land in question.

Any order for the eviction of an unlawful occupier or for the demolition or removal of buildings or structures in terms of this section is subject to the conditions deemed reasonable by the court; and on good cause shown, the court may vary any condition for an eviction order. ${ }^{34}$

The PIE Act also makes provision for an urgent application to evict in exceptional circumstances as stated in the section. ${ }^{35}$

\section{Conclusion}

It should be clear from these provisions that a number of matters should be considered when applying the PIE Act to an insolvent debtor and/or his or her dependants in bringing an application to evict them from a building or structure forming part of the insolvent estate. It should be clear that where the insolvent and/or his or her dependants still occupy property after sequestration, the trustee has locus standi (in view of the definition of "owner") to bring an application for eviction by following the PIE Act. It is submitted that this is the case since the Insolvency Act does not state that such occupation becomes unlawful by the mere issuing of a sequestration order. In fact, the continued basis of occupation will be determined by the trustee, probably acting on instructions of the creditors, since the trustee is deemed to be the "owner" in terms of section 20 of the Insolvency Act, but he or she is also the person legally in charge of the land.

From a practical point of view, and if the insolvent still occupies the land at the time that the estate property vests in the trustee, it is submitted that the

S 4(8) of the PIE Act.

33 See Brodie $v$ Kgomasang supra par 27, where it was made clear that the unlawful occupant is entitled to get notice, which must be a fair period: "It is clear that part of the fairness contemplated by PIE is that unlawful occupiers are given a period of time to vacate their homes that is just and equitable. Although it is not explicitly stated, this necessarily means that they must be given sufficient notice to do so."

34 S 4(12) of the PIE Act.

$35 \mathrm{~S} 5$ of the PIE Act. 
trustee should provide a notice to the insolvent to vacate the premises as a result of the sequestration process in order to make it clear that he or she may no longer occupy the premises - except where the trustee in fact allows the insolvent to remain in occupation. ${ }^{36}$ It is important, for purposes of an eviction application, to establish that the insolvent occupies unlawfully since this is a requirement for application of the PIE Act.

In general, where the insolvent remains in occupation of the family homestead, it is a building or structure (as included in the definition) that is occupied, but it must be noted that the insolvent may have vacated the house and moved into a caravan, perhaps parked on the land on which the house stands, or on another property of his or hers or the land of someone else.

The trustee in his or her official capacity as owner and as the person legally in charge of the estate property may bring an application to evict the insolvent if his or her occupancy is deemed to be unlawful. As far as the process is concerned, the trustee should follow the procedural imperatives of the PIE Act but in principle it must also be established that the occupancy by the insolvent is unlawful.

It is clear that, if the court finds the occupancy to be unlawful, the insolvent may ask the court not to grant the eviction order owing to circumstances that the court may consider as relevant considerations for the purposes of deciding on the order it should make. The court has broad powers in making a suitable order and, even where eviction is ordered, the court may determine the terms and conditions, for instance, of when the occupant must vacate the property. It must be noted that even in such an instance, where an eviction is ordered, the Act provides some temporary relief for the occupant. At least, this relief grants him or her time to find alternative accommodation.

Muller et al, ${ }^{37}$ with reference to Port Elizabeth Municipality $v$ People's Dialogue on Land and Shelter, ${ }^{38}$ state that the PIE Act is welfare legislation and cannot be approached from a legalistic point of view since it relates to social and economic factors tied up with fairness, morality and social values, as well as humanity and dignity for all persons. ${ }^{39}$ Clearly, in view of a more sympathetic approach detected among some judges, this scenario may lead to a more insolvency-specific approach in future. In this regard, it is submitted that the factors considered in Jaftha $v$ Schoeman; Van Rooyen $v$ Stolt $z^{40}$ and subsequent cases also may be relevant in order to guide the courts as to these considerations, although this line of cases dealt with attachment of the primary residence of the debtor.

36 See for instance Starbuck NO v Halim (12535/ 2015) [2015] ZAGPPHC 839 par 2, where the trustees served the occupants with written demands to vacate the property.

37 Muller et al Silberberg 756.

382000 (2) SA 1074 (SE).

39 See judgment of the Constitutional Court in Port Elizabeth Municipality v Various Occupiers supra.

402005 (1) BCLR 78 (CC). Further see Steyn Statutory Regulation of Forced Sale of the Home in South Africa $63 \mathrm{ff}$ at fn 27 above whose points raised are supported. 
Should an insolvent succeed in maintaining his or her occupancy of the home, it may become relevant to ask how this will be resolved in the long run, since an extended stay may be to the prejudice of creditors relying on the proceeds of the sale of the property and runs contrary to the principle that an insolvent estate should be wound up within a relatively short time span. These questions are not answered by the PIE Act since the Act clearly was not written with an insolvency situation in mind.

Where occupancy is legal, cadit questio; if the insolvent is able lawfully to remain in occupancy, an essential element of the application will be absent.

It is also important to take note that the property of the insolvent may be sold in different ways following the sequestration of his or her estate. The trustee is tasked with taking care of the property of the insolvent and must ensure that it remains intact. On instruction of the creditors, the property may be sold out of hand or by tender, but usually it will be sold by way of a public auction.

It must also be noted that, compared to an attachment and judicial sale following an individual execution procedure, the position in insolvency may be different. There is clear authority that where the debtor's estate has not been sequestrated, then occupation of his or her own house as a rule only becomes unlawful when the property is sold and registered in the name of the purchaser. ${ }^{41}$ The purchaser then in terms of the PIE Act is saddled with the process to evict the occupant. This is different from the case of sequestration where, as stated above, the property no longer vests in the insolvent from commencement of sequestration, but vests in the trustee. It is submitted that the trustee may need to take steps to give notice to the insolvent to vacate before occupation will be deemed unlawful. Put differently, the mere fact of sequestration may not make continued occupation by the insolvent unlawful. In some instances, the trustee will be faced with a situation that requires considering assisting the insolvent to rent other premises or allowing the insolvent to continue to stay on the property, sometimes in terms of a "rental" agreement. All these positions need careful consideration by the trustee and creditors since there are pros and cons attached to these options. From a practical point of view and to provide certainty, the trustee should inform the insolvent in writing if he or she must vacate the premises in order to prevent an evidential issue arising concerning the lawfulness or otherwise of the occupation. As indicated, an eviction application may be brought only against a person who occupies unlawfully.

It must be noted that an insolvent may vacate his or her house before or on sequestration and find him- or herself a place of dwelling in, for instance, a caravan or may rent some form of housing from a third party. It is submitted that the eviction of the insolvent under such circumstances and under circumstances where his or occupation has become unlawful may also trigger the application of the PIE Act. In such cases, basic principles should be adhered to and the owner or person in charge must still be identified to bring the eviction application.

41 Sediba v United Building Society 1993 (3) SA 671 (T). 


\section{RELEVANT CASE LAW REGARDING THE APPLICATION OF THE PIE ACT IN INSOLVENCY}

A number of insolvency cases have dealt with aspects of the PIE Act to date. In this section, the most relevant cases in this regard will be discussed. The section must be read against the backdrop of the discussion of the PIE Act under heading 6 of this article above.

\section{$71 \quad$ ABSA Bank v Murray ${ }^{42}$}

In this case, a mortgaged property - the family home of the insolvents (a husband and wife married in community of property) - was sold out of the joint insolvent estate by way of a public auction. ABSA Bank, the former mortgagee, purchased the property at the auction. The bank resold the property but since the insolvents still occupied the property by way of holding over the erstwhile mortgaged property, it instituted an application for the eviction of the insolvents in order to give vacant possession to the purchaser. At the time of the application, the insolvents had occupied the property for longer than six months. (In order to have had locus standi to have lodged the application, it is assumed that the bank was still the owner of the property at the time of its eviction application. $)^{43}$

It seems the bank, as applicant, followed the PIE Act procedures and the respondents relied on the grounds of "just and equitable" as mentioned in the PIE Act since they had no common-law defence to raise against the eviction order. ${ }^{44}$ The court accepted that the insolvent respondents had been in unlawful occupation for more than six months when proceedings were initiated and it deemed sections $4(7)$ and (8) to be central to the determination of the application. ${ }^{45}$ In paragraph 15 of the judgment, the court noted that the occupation of the property by the insolvents initially was "lawful due to their previous ownership of the property but subsequently terminated by their sequestration and the consequent realisation of the property by the bank". ${ }^{46}$ This remark may point to authority that sequestration per se may cause the occupation to become unlawful but the full sentence must be read - that is, the court refers to sequestration and consequent realisation of the property. Also, it can be accepted that the bank requested the insolvents to vacate, which it was entitled to do as owner of the property. As to whether there was permission to remain in occupation,

422004 (2) SA 15 (CPD).

43 Par $1-2$.

44 At par 17 read with 23 , the court accepted that the common-law grounds for eviction were altered by the PIE Act and the effect of s 26(3) of the Constitution was twofold: first, it imposed a duty upon courts to investigate and address considerations of justice and equity in determining the application for eviction; and, secondly, it provided a broad discretionary power to the court to impinge on the common-law right to obtain possession by the owner to the extent that considerations of justness and equity demand.

45 Par 5.

46 The court at par 13 also applied the interpretation in Ndlovu v Ngcobo supra - namely, that the PIE Act will apply to a case of holding over where the occupation was legal initially but became illegal at a later stage. 
the author maintains this to be a factual question; in a case such as this, where the insolvent remained in occupation of the property after commencement of sequestration, the question must be considered for the purposes of bringing the matter within the purview of the PIE Act. Some indirect support for this approach is to be found, in that the court mentions that the insolvents had been aware for over a year of the bank's intention to evict them. ${ }^{47}$

The point of departure for the court regarding the eviction application therefore was a duly-formed opinion that it would be just and equitable in all the relevant circumstances to grant an order for eviction; ${ }^{48}$ in the words of the court, " $t$ the 'validity' of the defence depends upon the determination of what would be just and equitable". 49 The court was mindful of the balance to be struck between the proprietary rights of the owner and the basic human rights of the occupier in making a determination. ${ }^{50}$

The respondents argued that it would not be just and equitable for the court to grant the eviction order and raised the following facts to convince the court not to grant the eviction order, ${ }^{51}$ namely:

1. They and their family had lived in the house for almost 20 years.

2. They had not wilfully defaulted on the mortgage bond repayments. The reason for the default was first respondent's loss of employment by reason of a worker complement reduction retrenchment process instituted by first respondent's erstwhile employer. The first respondent had paid R36 000.00 of his retrenchment package in reduction of the mortgage debt, before being sequestrated.

3. The first respondent conducts a business from the garage on the property with the permission of the trustee of respondents' insolvent estate. The first respondent needed the space thus provided to earn a living.

4. The first respondent had offered to pay rent on the property.

5. The first respondent had asked the bank for time until the end of 2002 to raise the funds to repurchase the property. He explained that he intended to do this from the proceeds of an MVA award that his brother expected to receive.

6. The respondents' grandchild (just over 2 years of age) and an 11-year old girl placed in the respondents' care lived in the house together with the respondents.

7. The respondents and their family have no alternative place to stay.

The applicant, however, argued that these factors were legally irrelevant and afforded no basis to refuse the order. ${ }^{52}$ After lengthy reasoning, the court

47 Par 48. The court also mentioned that they had occupied without recompensing the owner.

48 Par 19.

49 Ibid.

50 Par 21, where the court states that "[i]t does not provide for the negation of either class or category of rights and leaves it to the courts to endeavour to address tension between them justly and equitably".

51 Par 4 and 6 .

52 Par 9. 
rejected this argument. ${ }^{53}$ The exception to having to consider just and equitable considerations (where the property has been sold in execution as provided for in sections 4(6) and (7)) was deemed to be central to the matter and thus also considered, but the court held that the exception in section 4(7) would not apply since the house was sold in terms of section 83(8) of the Insolvency Act ${ }^{54}$ and not by an execution sale as provided for in the section 4(7) exception. ${ }^{55}$ Therefore, the facts raised by the insolvents should be considered by the court.

Although the court took a liberal view concerning the assistance to be provided by courts in view of section 26 of the Constitution, ${ }^{56}$ as well as the provision of the PIE Act, ${ }^{57}$ in the end it granted the eviction order since it concluded that the respondents did not qualify for any special consideration in justice and equity entitling them and their dependants to remain in occupation of the property against the owner's right to possession. ${ }^{58}$ The following reasons were advanced by the court:59

"The respondents' occupation of the property was a consequence of a mortgage loan contract with the applicant, which had afforded them the financial means to acquire possession of the property. Interference with the effectiveness of the bank's security in cases like this could have far reaching adverse consequences in the housing market inimical to the realisation of the object of the progressive provision of access to housing by the broader community.

The first respondent is a relatively sophisticated and economically active member of the community who was able to provide independently for the needs of his family and dependants, within the limits of his income. $\mathrm{He}$ is a small-scale entrepreneur who has established a successful business. The first respondent had in fact offered to pay rent to the applicant. With adequate notice to make arrangements to move to alternative accommodation, there is no reason to believe he will not be able to continue to provide adequately for his and his dependants' basic needs.

The respondents had been aware for over a year of the bank's intention to evict them and accordingly they had already had a considerable period, during which they have occupied the property without any recompense to the owner, to prepare to vacate the property. Accordingly, in terms of ss 4(8) and (9) of the Act, I considered that a period of approximately 6 weeks' notice to vacate the property before an eviction order could be executed was just and equitable in the circumstances."

53 Par 10-18.

5424 of 1936.

55 Par 27.

56 Par 17, where the court mentioned that the substantive reforming effect of $s 26(3)$ of the Constitution was that: first, it unambiguously places a duty upon courts to investigate and address considerations of justice and equity in determining any application for the eviction of any person from his or her home; secondly, it clothes the court with a discretionary power to impinge on the common-law right of the owner to obtain possession of the property to the extent that consideration of justness and equity demand.

57 See for instance par 19, 23, 2838 and 39.

58 Par 44.

59 Par 46 to 49. 
The importance of this case lies first in that it accepted the applicability of the PIE Act after sequestration, and considered factors to be used to decide whether the insolvent occupant should be evicted following the provisions of the Act. The judgment made clear that the interests of both parties must be considered - especially since the applicant in the matter was the mortgagee. 60 It must be noted that the mortgagee was the applicant in the eviction application since it bought the property from the insolvent estate. Eviction was sought in order to give possession of the property to the person who purchased it from the mortgagee (the bank). The court clearly pointed out that it did not amount to an execution sale and that the exception provided for in section 4(7) therefore would not apply. ${ }^{61}$

In this case, with reference to the ambit of the Act, it was held that the PIE Act applies in cases where occupancy initially is legal but becomes unlawful at a later stage. ${ }^{62}$ It is assumed that the occupation became unlawful when the bank (as the new owner) instructed the insolvent to vacate in view of the fact that it had purchased and resold the property and needed to give vacant possession to the new owner. ${ }^{63}$

Some of the court's remarks remain important - namely, that one of the requirements of section 4 of the PIE Act, to grant an order for eviction, is a duly formed opinion that the eviction would be just and equitable in all the relevant circumstances, also considering the rights and needs of the occupant. ${ }^{64}$ The court made an important observation:

"The enquiry, in at least insofar as it takes into consideration the effect of an eviction on the person sought to be evicted, will be influenced particularly by the consideration of the effect on that person's basic rights, including that person's constitutional socio economic rights."

The courts need to be sensitive to the social and economic repercussions of exercising the important responsibility granted them by the PIE Act to regulate property rights; this means contextualising the immediate circumstances of the case in terms of the national and social and economic microcosm. ${ }^{65}$ It must be remembered, as pointed out by the court in paragraph 32, that the PIE Act does not provide a mechanism to divest an owner of property; it simply affords a basis upon which the judiciary can and must regulate the exercise of proprietary rights to possession against the unlawful occupier ("to whom the property has become home") in a way that, as far as is practically achievable, is consistent with the Bill of Rights and the founding principles of the Constitution. The court did not want the

60 Par 21.

61 Par 26 and 27. In this regard, the court at par 25 referred to Ndlovu $v$ Ngcobo supra par 10, where the court found $s$ 4(7) and (8) to be anomalous with regard to the exception following an execution sale in that the rights of the elderly, children, disabled persons and households headed by woman would not have to be considered.

62 Par 13 and 15 with reference to the SCA judgment in Ndlovu v Ngcobo supra.

63 Par 2.

64 Par 22.

65 Ibid. 
consideration of such circumstances tied down to a hard-and-fast burden of proof. 66

The court discussed the reason that local municipalities are formally informed of eviction applications as provided for by the Act: it is to assist the courts in realising socio-economic constitutional rights pertaining to housing, water and related matters. In this regard, the local municipality should assist the court to make decisions that are truly just and equitable. The court mentioned that apparently it is the norm that municipalities do not report to the courts in practice. ${ }^{67}$ However, it should be noted that there seems to be a greater reluctance by municipalities to get involved in matters where the land is private land. Ultimately at play here is the question whether the occupant will be able to find suitable alternative accommodation if he or she is evicted. Trustees who bring eviction applications may of course also assist the court by indicating whether it is possible for the insolvent to find alternative accommodation and may even make proposals in this regard.

The $A B S A v$ Murray case offers a peculiar set of facts where the bank purchased the property from the insolvent estate of the insolvent occupier after sequestration of the estate and then applied for eviction but the same considerations will apply if the trustee applies for an eviction order.

\section{Mayekiso v Patel NO68}

This case concerns an appeal against an eviction order following an application in terms of the PIE Act by the trustees of an insolvent joint estate granted against Mr and Ms Mayekiso, the insolvents and the appellants in the current matter. The eviction order granted by the court a quo in 2016 related to their most luxurious house in which they resided for a number of years after sequestration and which was finally sold as part of the estate's assets. ${ }^{69}$ The court a quo granted the eviction application on the ground that the appellants' continued occupation of the house after its sale in execution was unlawful. In an appeal to the full bench, the appellants, who conceded that their occupation was unlawful, ${ }^{70}$ argued that the court a quo had failed properly to consider the effects of the eviction on the family, particularly the minor children.

The facts giving rise to the appeal include that the main asset in the estate is a luxury house purchased in 2007 for R19.95 million rand in cash. ${ }^{71}$ The insolvents experienced financial difficulties after 2011 but thwarted an attempted sale in execution in 2014 by an urgent application for sequestration of the joint estate. Their joint estate was subsequently

66 Par 38: "I consider that it is inappropriate to fix an ultimate onus of proof on either side. The court's decision falls to be made on the basis of all the relevant facts and considerations available to it." It is to be noted that the SCA found it unnecessary to decide this point in that matter; see Ndlovu v Ngcobo supra par 19.

67 Par 40 and 41.

682019 (2) SA 522 (WCC).

69 Par 4-10.

70 Par 21.

71 Par 4. 
sequestrated in $2014 .^{72}$ The house had a market value of R18m in 2015 and a so-called forced sale value of $\mathrm{R} 13 \mathrm{~m}$. The insolvents and their two minor children nevertheless remained in occupation of the house after sequestration. The joint trustees of the estate were formally directed and authorised by written resolution of the creditors at the second meeting of creditors to dispose of any movable and immovable property of the estate. ${ }^{73}$ On 1 December 2014, the trustees made an offer to the insolvents to accommodate their continued occupation of the house as tenants in terms of a formal lease agreement. ${ }^{74}$ The fate of these negotiations is not absolutely clear but the insolvents were not interested in paying rental to the trustees in order to continue occupying the property. ${ }^{75}$ The property was ultimately sold in 2017 for R13.2m. (It must be noted that a contract of lease entered into between a trustee and an insolvent may complicate the eviction process but it is understandable that the trustee will try to recuperate some expenses in relation to the property while the insolvent still occupies the premises. It could be asked what the object of such a rental agreement will be since, although the sequestration divests insolvents of their property, they retain a residual interest in it; it is submitted that it would be the right to occupy and to use it.)

The appellants, having earlier accepted during the appeal that the property had to be sold to satisfy creditors' claims, ${ }^{76}$ nevertheless made an application (among others) to introduce new evidence on appeal - much of it hearsay - to show that one of the trustees was an impostor and not trustworthy ${ }^{77}$ and they argued that this state of affairs rendered the eviction application fundamentally flawed. ${ }^{78}$ This request was rejected by the majority judgment of the court of appeal.

Another point raised by the insolvents was that, since they were the registered owners of the property, they asserted a residual right therein and, based on this claim, they challenged the right of the trustee to deprive them of their occupancy of the property and, as mentioned before, they objected to the request to pay rent. In essence, they argued that their ownership entitled them to occupy the property without paying rental for their right of occupation. ${ }^{79}$ The court, with reference to Hendricks $v$ Hendricks, ${ }^{80}$ remarked on this point that the ownership could not amount to the bare dominium in the property. This matter, as well as the objection to locus standi of the trustee was not persisted with in the appeal case.

Following the sequence of events, the trustees continued to offer the property for sale on a public auction. ${ }^{81}$ The insolvents at one point brought an urgent application in an attempt to stop the sale of the property and the

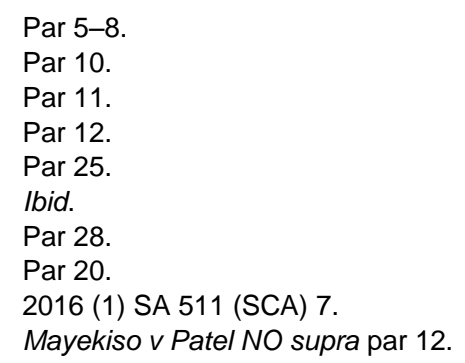


court was informed that this was an attempt to save the family home. ${ }^{82}$ This application was rejected since the court hearing this earlier application found the applicants had no locus standi to intervene in the matter. ${ }^{83}$ Hence, the trustees continued with the sale of the property as they had a statutory obligation to realise the assets of the insolvent joint estate. The trustees brought an eviction application in which they indicated that the matter had become urgent since the property was deteriorating on a daily basis, which of course was to the detriment of the creditors. ${ }^{84}$

In opposing the later application to evict them from the house in the court a quo, the insolvents raised a number of substantive as well as procedural defences. They claimed that, since they were still the registered owners, they retained a residual right to challenge the trustees to deprive them of occupation of the property. ${ }^{85}$ They also argued that, as they were still registered owners, they could not be expected to pay rental. ${ }^{86}$ The court a quo however did not accept the argument that their occupation was lawful and indeed concluded that it was unlawful; 87 this finding rendered the PIE Act applicable. Their argument that the trustees had no locus standi to bring the eviction application raised in the court of first instance was not again raised on appeal. ${ }^{88}$

In view of these concessions, the end result of the appeal was that the appellants relied on the defences provided for in the PIE Act by claiming that the effects of an eviction order in relation to their minor children and the Mayekiso family being left homeless were not properly considered by the court a quo. ${ }^{89}$ On appeal, the insolvents ultimately accepted that the property would have to be sold in the end but argued that there would be no risk if they remained in the house and indicated that they would vacate once the property had been sold and registered in the name of a third party. ${ }^{90}$ As indicated above, the property had in fact been sold on 18 September 2017 and the trustees mentioned that the appeal in fact became moot in view of the undertaking to vacate the premises. ${ }^{91}$

After the appellants (the insolvents) made certain concessions regarding technical points raised as part of the appeal, the court narrowed down the issues for the purposes of the appeal to the argument that the court a quo failed to have proper regard for the effect of an eviction order on the parties' minor children and further failed to consider the prospect that eviction would render the Mayekiso family homeless. ${ }^{92}$

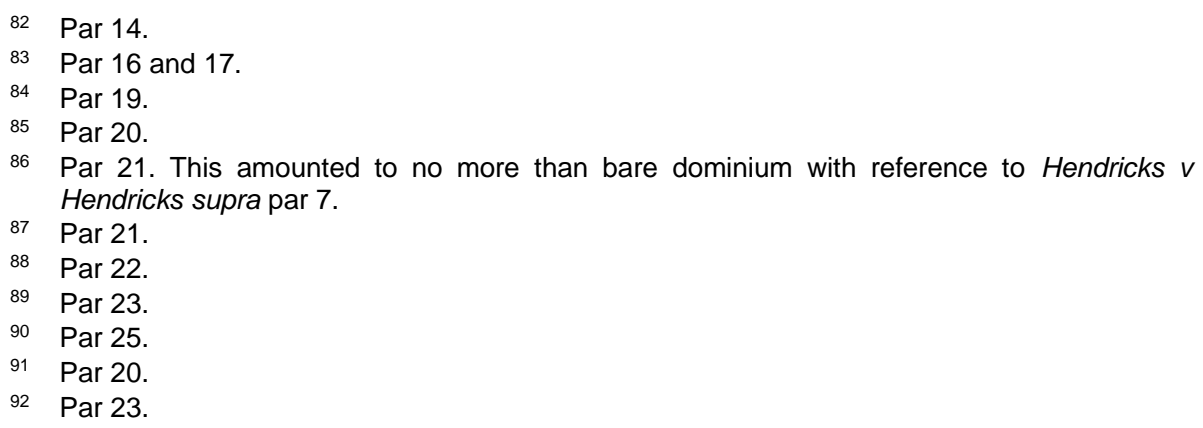


The respondents (the trustees) argued that the appeal had become moot since the appellants agreed they would vacate the premises once the property had been sold, and the fact that the property had been transferred to the purchaser. ${ }^{93}$

An important matter considered on appeal was whether the decision of the court a quo was just and equitable. The appellants relied heavily on the judgment in Port Elizabeth Municipality $v$ Various Occupiers ${ }^{94}$ and the Berea judgment ${ }^{95}$ in their submissions that Dolamo $\mathrm{J}$, the judge of first instance, had failed to discharge his constitutional duty in ordering the eviction. The court on appeal indicated that these were not the only authorities to be considered; and mentioned that the application of the PIE Act and the removal of unlawful occupiers of land had generated a considerable body of law in the last 15 years or so with leading appellate cases such as Ndlovu, ${ }^{96}$ Blue Moonlight ${ }^{97}$ and Changing Tides $^{98}$ featuring prominently in the debates before our courts.

In this regard, the argument was raised that the court a quo did not have sufficient evidence before it about the precarious position of the minor children should the eviction order be granted and about the hardship it would cause owing to the homelessness of the family and the displacement of family members. ${ }^{99}$

The court of appeal concluded that the application by the appellants to adduce further evidence was not bona fide; the appeal had to be decided on the record as it stood together with the relevant common-cause facts. ${ }^{100}$

In deciding the matter, the court indicated that the facts of each case of alleged illegal occupation are the point of departure ${ }^{101}$ and in applying the established jurisprudence, when a court applies section 4(6) and (7) of the PIE Act, being the statutory instrument that underpins the section 26(3) basic right, the court needs to know, inter alia:

- $\quad$ whether the land in question is privately owned or whether it belongs to the State (or an arm of government);

- $\quad$ how long the land has been illegally occupied;

- how many people/families/households are likely to be affected by the proposed eviction;

- how many of those households are headed by women;

- how many children are likely to be affected, what their ages are, whether they attend school and if so where;

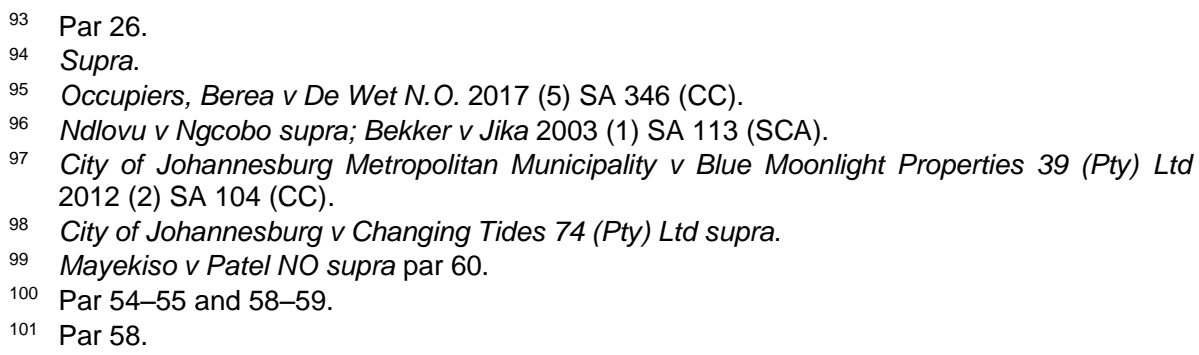


- $\quad$ whether there are sick or disabled occupiers who might be dependent on public health care;

- whether homelessness is likely to ensue; and

- what alternative options, particularly in respect of emergency housing, can be made available by the local authority concerned.

As to the merit of the defence raised by the appellants, the court found that the presence of children on the property did not necessarily trump the right of the owner (the trustee) to seek the eviction of their parents. ${ }^{102}$ Save for raising the possibility of homelessness, the appellants did not point out other factors relating to the children that the court a quo considered material, and the reason was clear, there were none. ${ }^{103}$ The appeal bench accepted that the court a quo gave full consideration to the issue of homelessness and the effect it might have on the minor children, which was the only context in which the children's interests fell and needed to be considered. ${ }^{104}$ But the appellants' continuing opulent lifestyle and their ability to conduct drawn-out and expensive litigation suggested unequivocally that homelessness was not a likely consequence of their eviction. ${ }^{105}$ It was pointed out that this situation was confirmed by the first appellant, who promised under oath that the family would move out when the property was sold and transferred to its new owner.106 Accordingly, it was for the court just and equitable in the circumstances to grant an order of eviction. ${ }^{107}$ The court in the end did not accept that eviction would render the Mayekiso family homeless and also was not prepared to entertain further evidence on the matter on appeal. ${ }^{108}$

It is interesting to note that the court a quo, in granting an eviction order, granted the insolvents a 30-day time of grace to remain on the property with a view to entering into a deal with the trustees concerning a way to save the property that was their home. This grant was made subject to the condition that potential buyers would have reasonable access to the property and that the insolvents would pay the rates and taxes during the remainder of their stay on the premises. ${ }^{109}$

In confirming the ultimate eviction order granted by the court a quo, the court of appeal provided a reasonable time for the appellants to vacate the premises. In this way, the needs of the unlawful occupants were addressed to an extent since even where the circumstances do not warrant continued occupation, the court may rule under what conditions the occupant must

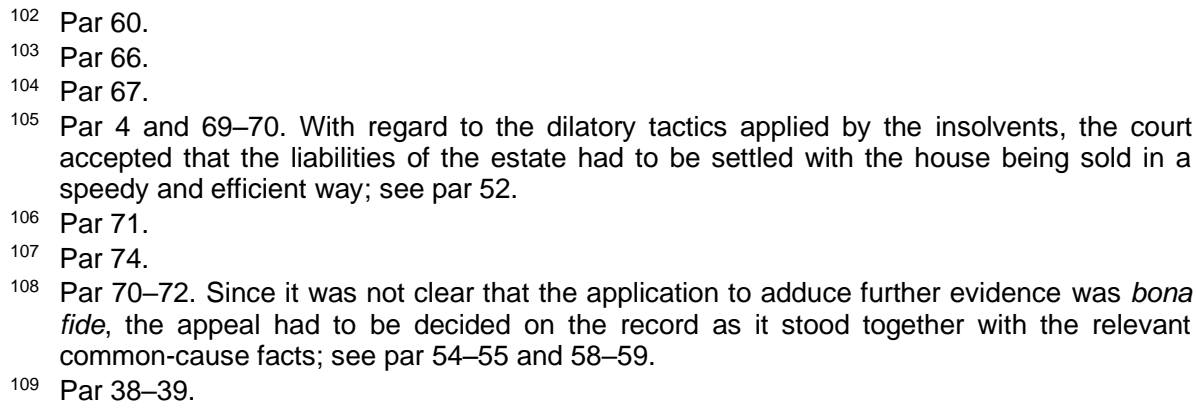

105 Par 4 and 69-70. With regard to the dilatory tactics applied by the insolvents, the court accepted that the liabilities of the estate had to be settled with the house being sold in a speedy and efficient way; see par 52.

106 Par 71.

107 Par 74.

108 Par 70-72. Since it was not clear that the application to adduce further evidence was bona fide, the appeal had to be decided on the record as it stood together with the relevant common-cause facts; see par 54-55 and 58-59.

109 Par 38-39. 
vacate the property. In this regard, factors such as the end of the school term are taken into consideration. ${ }^{110}$

In a minority judgment, the dissenting judge, Mantame $\mathrm{J}$, came to a different conclusion and indicated that both the appellant and the respondents should be given the opportunity to adduce further evidence. ${ }^{111}$ In essence, he accepted that the court a quo had to look more closely at the position of minor children and the matter of homelessness. The judge alluded to a more liberal approach followed by the courts. He concluded that the sophistication of the appellants' lifestyle was not a sufficient reason not to protect occupancy; he held that the court could not assume that, because the appellants occupied a R19.95 million house, they could not be rendered homeless by eviction. ${ }^{112}$ The learned judge held the opinion that due process required that an inquiry be made ${ }^{113}$ and concluded that the court a quo should have investigated the appellants' arrangements for alternative accommodation and enquired into the circumstances of the children. ${ }^{114}$ Thus, a broader investigation into relevant circumstances as intended in section 4(7) of the PIE Act was supported in the minority judgment. The importance of the statutory obligations of municipalities as prescribed by the PIE Act were also highlighted in this minority judgment. ${ }^{115}$

\section{Body Corporate of Redberry Park v Sukude NO116}

This was an application for provisional sequestration order by means of compulsory sequestration against an insolvent deceased estate of the late Mr Sukude. The applicant-creditor was the Body Corporate of Redberry Park, established in terms of section 36 of the Sectional Titles Act; ${ }^{117}$ the insolvent estate was indebted to the body corporate for payment of the statutory imposed levies.

Important to this discussion is that the founding affidavit of the applicant mentioned that an order for sequestration would avoid any problems with possible defences under the PIE Act, which would lead to delays and further prejudice. Although not specifically elaborated on in the judgment, it is assumed that family members of the deceased insolvent debtor occupied the sectional title unit. The applicant raised this matter apparently to convince the court that sequestration would be to the advantage of creditors since, it seems, the argument was that a sequestration order would prevent any unlawful occupant from raising the defences in the PIE Act that might prevent the "owner" from evicting occupants from the premises as it would

\footnotetext{
110 Par 76.

111 Par 45 of the minority judgment.

112 Par 35 of the minority judgment.

113 Par $28 \mathrm{ff}$ of the minority judgment.

114 Par 41 of the minority judgment.

115 Par 32-33.

116 [2015] JOL 33408 (KZD).

11795 of 1986.
} 
obviate problems caused by the defences raised in terms of the PIE Act. During argument, the applicant abandoned this suggestion. ${ }^{118}$

The court held the opinion that the property should in fact be sold in execution and was not convinced that sequestration would be to the advantage of creditors or serve any other purpose. The court agreed that the point relating to the potential advantage of granting a sequestration order with reference to an avoidance of the effects of the PIE Act should be abandoned and mentioned that the court had no doubt that that was in the mind of the applicant when the papers were drawn. ${ }^{119}$ The court also held the view that such reasons may not be legitimate when seeking to issue sequestration proceedings as opposed simply to following the normal execution process. ${ }^{120}$ This argument did not convince the court that it should exercise its discretion in terms of section 10 of the Insolvency Act ${ }^{121}$ to permit the sequestration of the deceased insolvent estate.

In refusing the application for sequestration for lack of proof of advantage to creditors, the court stated that it was not clear why it became necessary for the administrator to be granted an order for the sequestration of the insolvent estate of Sukude (the erstwhile sectional title holder) when there was no apparent reason that the property could not be sold in execution.

The court mentioned that although the applicant did not eschew any reliance on the avoidance of the consequences of the eviction of persons from the unit as a basis for justifying sequestration proceedings, there is no doubt that that was in the mind of the administrator when the papers were drawn. In addition, a main reason the administrator wished to proceed with a sequestration process was to secure an advantage over the mortgagee. The court concluded: "[i]n my view neither of those are legitimate reasons for seeking to issue sequestration proceedings as opposed to simply following the normal execution process against immovable property".

It must be stressed that this application dealt with a compulsory sequestration application. It seems the applicant initially attempted to convince the court that a sequestration order would be to the advantage of creditors since this is one of the key requirements to obtain such an order. In support of factors supporting the advantage of creditors, the applicant apparently tried to imply that the PIE Act would not be applicable after sequestration regarding the eviction of unlawful occupants and, hence, would benefit the body of creditors. Although this point was abandoned during the application, it must be noted that sequestration per se does not obviate the application of the PIE Act. The exception in section 4(7) of the PIE Act will also not avail the applicant in a subsequent eviction order since a sale following sequestration is not an execution sale as envisaged in the section.

Nevertheless, the application for sequestration was dismissed since no information was disclosed by the administrator as to the relative costs of recovering the debt via a sequestration process as opposed to levying

118 Body Corporate of Redberry Park v Sukude NO supra par 9.

119 Par 11.

120 Ibid.

12124 of 1936. 
execution against the sectional unit in the normal course. The application contained no further indication as to the costs of sequestration. Had these aspects been fully dealt with by the administrator, it would have been of some assistance in arriving at the proper exercise of the court's discretion. ${ }^{122}$

For the purposes of this article, it is important to note that the court, while considering the advantage-to-creditors requirement, merely accepted that a possible motive for bringing the application was that the applicant thought the sequestration order would obviate/override any defences that may be raised against an eviction claim based on the PIE Act. It seems that there was an issue regarding current occupants of the sectional title unit of the deceased - perhaps family members occupying the unit. On a proper reading of the judgment, the court apparently accepted that such an ulterior motive was in the mind of the applicant, and questioned its legality. The effect of the position taken on the matter is that the court did not want to upset occupants who are entitled to seek the protection offered by the PIE Act from using it when faced with an eviction order.

However, it is clear that granting a sequestration order would not per se prevent the occupants from relying on certain statutory defences provided by the PIE Act when faced with an eviction order.

\section{$74 \quad$ Botha NO v Kies $^{123}$}

In this case, the joint trustees in the insolvent estate of the first respondent launched an eviction application on 12 July 2012 against the respondents, which was opposed. At the time of the application, the first and second respondents occupied a sectional title unit, number 2 in a sectional title scheme. The first respondent purchased the property on 28 September 2004 for the amount of R540 000.00 and it was registered in the first respondent's name on 17 March 2005. During 2005 and 2006, two sectional mortgage bonds were registered in favour of First National Bank (FNB), which provided security in the aggregated sum of R1 $440000.00 .{ }^{124}$

On 23 April 2012, and after their appointment, the applicants demanded that the first respondent vacate the property, which notice was served personally on the first respondent on 2 May 2012; he refused to comply with the demand. ${ }^{125}$

Against this eviction application, the first respondent, Mr Kies, raised the defence that a person cannot be a squatter in his own house ${ }^{126}$ - an insolvent cannot occupy "his" or "her" property unlawfully, even after sequestration, according to the argument. The first respondent then alleged that the applicants had no locus standi and that the provisions of the PIE Act were not applicable. ${ }^{127}$

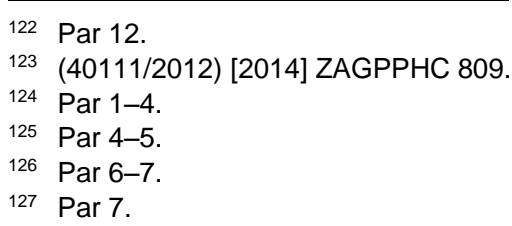


However, the court referred to the provisions of the Insolvency Act, ${ }^{128}$ which state in section 20(1) that an insolvent is divested of his estate (the insolvent estate vests in the Master of the High Court, and upon the appointment of the trustees, it vests in them). The Insolvency Act provides that all the property, which according to the definition in the Act includes "movable or immovable property wherever situated within the Republic", so vests in the Master and then in the trustee upon his or her appointment. ${ }^{129}$

At the time of the application, the applicants, in their official capacities, were the owners of the property. The court found that, in view of section 2 read with section 4 of the PIE Act, they had the necessary locus standi to launch the present application. ${ }^{130}$

The insolvents occupied the property without any form of consent from the trustees and the court therefore found them to be the unlawful occupiers of the property. ${ }^{131}$ In particular, the court stated: "[t]here is no doubt in my mind that the PIE Act applies."

The court quoted Bekker $v$ Jika ${ }^{132}$ at paragraph 11, where Harms JA stated:

"Since the factors discussed are essentially neutral, one is left with the ordinary meaning of the definition which means that (textually) PIE applies to all unlawful occupiers, irrespective of whether their possession was at an earlier stage lawful."(court's emphasis)

At paragraph 19, Harms JA went on to state:

"Unless the occupier opposes and discloses circumstances relevant to the eviction order, the owner, in principle, will be entitled to an order for eviction. Relevant circumstances are nearly without fail facts within the exclusive knowledge of the occupier and it cannot be expected of an owner to negative in advance facts not known to him and not in issue between the parties." (court's emphasis)

In its judgment, the court in Botha NO $v$ Kies noted in paragraph 18 that it was patently clear that the first respondent was factually insolvent and that there was no equity in the estate.

Relevant to the reasoning of the court was the fact that the creditors at the second meeting of creditors authorised the trustee to sell the property as directed in one of the resolutions adopted at the meeting, ${ }^{133}$ as follows:

"That the trustee be, and is hereby authorized, to sell or in any other way dispose of any immovable or movable assets of the Insolvent Estate, whether as a going concerns, or otherwise, or whether separately or jointly, with any other person or corporate entity, and on such terms and conditions as the Trustee, in his sole discretion, may decide on and particularly, in his sole discretion, should they decide to sell or otherwise dispose of any such asset, jointly with any other person or corporate entity, on the method and quantum,

12824 of 1936.

129 Par 8.

130 Par 9

131 Par 12.

132 Supra (referred to as Ndlovu $v$ Ncgobo in this article).

133 Botha NO v Kies supra par 19. 
of division, of the total consideration, by public auction, tender or private treaty, and on such terms and conditions as he, the Trustee, in his sole discretion may deem fit and any other costs thereof which he, in his sole discretion cannot pass over, to be costs of sequestration."

In paragraph 20, the court states that the applicants cannot sell the property while the respondents are occupying the property - hence the application for the eviction of the respondents. It is submitted that this statement by the court should be restated to say that it may impact negatively on the sale value of the property if the insolvent still occupies the premises when the trustee wants to sell it but that such occupation in itself did not prevent the trustee from selling it in accordance with the creditors' resolution. (Clearly it may have a negative effect on the interest in the property should the insolvent still be in occupation at this time.)

In preparation for judgment, the court remarked that "[i]t is clear that the first respondent [that is, the insolvent] cannot accept that he has reached the end of the road and that he has no defence whatsoever". ${ }^{134}$

In support of the application, the court considered the fact that the insolvents had been occupying the property unlawfully, free of charge and to the detriment of the insolvent estate. Furthermore, each day the value of the property was diminishing owing to the lack of maintenance. It could not be marketed and sold and the proceeds distributed to the first respondent's creditors. It had been two years and four months since notice to vacate had been given to the respondents but to no avail. ${ }^{135}$ The court considered all the arguments by counsel for the applicants and the respondents and the provisions of the respective Acts. Important to the court was that the respondents, were not relying on the fact that they were "poor and vulnerable". ${ }^{136}$ The court mentioned that Mr Kies (first respondent) described himself as a pensioner and legal advisor; ${ }^{137}$ and therefore the only inference the court could draw was that he had an income. The court concluded that it would be just and equitable to grant the eviction orders as requested in these circumstances. ${ }^{138}$

It was determined that the continued occupation of the property was to the detriment of the concursus creditorum and could not be further tolerated; ${ }^{139}$ hence, the court granted the eviction order.

\section{Starbuck NO v Halim ${ }^{140}$}

In this case, an eviction order was granted against an insolvent husband and wife whose joint estate had been sequestrated. Their mortgaged home vested in their insolvent estate but they continued to occupy the premises together with three other persons. The insolvents were first and second

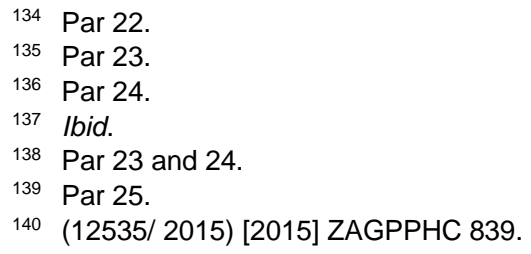


respondents in an eviction application brought by the trustees of their estate. After their sequestration, the insolvents apparently rented the house out without the approval of the trustees as required in terms of section 23(2) of the Insolvency Act. ${ }^{141}$ (The lessee, who also occupied the house was the third respondent in the eviction application.) No defence based on the PIE Act was raised by the respondents, and although the third respondent opposed the application on other grounds, the eviction order was granted against all the respondents. ${ }^{142}$ This case is not that significant except that it mentions that the trustees first sent eviction notices to the occupiers, including the insolvents, before bringing the eviction application. ${ }^{143}$ As proposed earlier in this article under heading 6, such a pre-application process is commendable in such a case in order to establish the element of unlawful occupation by the occupiers.

\section{CONCLUSION}

As indicated in the introduction in Part $1^{144}$ of this article, South African insolvency law does not provide direct protection for insolvents insofar as their family home after sequestration is concerned - for instance, by excluding it or some of its equity from the insolvent estate, or by providing for continued occupation after sequestration as is the case in some other legal systems. ${ }^{145}$

However, in view of section 26 of the Constitution, South African law has developed rules to protect the right to housing as guaranteed in the Bill of Rights. ${ }^{146}$ This development was initiated by case law but the genesis remains the basic rights enshrined in the Bill of Rights. The cases dealing with this matter concern the socio-economic rights of persons - in particular, the right to housing of vulnerable and insolvent debtors whose estates have not been sequestrated. It should be clear that many in fact were not eligible for sequestration owing to the statutory requirements for this process. The judgments, including those of the Constitutional Court, caused rules of individual attachment and execution to be amended in order to provide for judicial oversight in cases of individual execution of the residence of the debtor. ${ }^{147}$ This development by case law following the important Jaftha judgment resulted in legislative amendments to the High Court and magistrates' courts procedures dealing with these matters; due process was introduced in deciding whether execution of the primary residence of the debtor should proceed in particular circumstances. Factors to be considered by courts adjudicating such requests are referred to under heading 3 in Part 1 of this article.

As mentioned, these procedures currently are not applicable in a sequestration application and the question is whether these considerations

14124 of 1936.

142 Par 12-16 and 19.

143 Par 2.

144 See heading 1 in Part 1 of this article.

145 See heading 2 in Part 1 of this article.

146 See heading 3 in Part 1 of this article.

147 Ibid. 
spill over to sequestration applications and, more importantly for this article, whether there are any other measures that protect vulnerable insolvents faced with the prospect of being rendered homeless after the sequestration of their estates. ${ }^{148}$ It remains a question whether a court hearing a sequestration application will consider similar factors to those argued in applications for attachment and execution. In a recent case, Jordaan $v$ Jordaan ${ }^{149}$ an application for voluntary surrender did open the door in an indirect way for such an investigation and approach in the future. ${ }^{150}$ The granting of a sequestration order is governed by the Insolvency Act ${ }^{151}$ but it is submitted that a case could be argued on the lines of Jaftha and subsequent cases should the facts regarding the personal circumstances of the insolvent be similar. With reference to the advantage-of-creditors principle, the respondent-debtor (owner) may argue a case that the sequestration in any event will not be to the advantage of creditors or may indicate alternative arrangements or procedures that could be used in place of a sequestration order. The facts will determine what is or is not possible in this regard.

It seems the protection relating to attachment and execution initially applied to indigent home owners but the courts also had to deal with more affluent property owners, such as those who could afford mortgage bonds over the residences. ${ }^{152}$ In such instances, with the rights of secured creditors (the mortgagees) to consider, it seemed the courts were reluctant to provide similar protection. On the other hand, it must be conceded that a debtor who can afford a mortgage bond may well be in a better financial position than the atypical debtor in the Jaftha matter. After initial hesitation, later judgments did consider the plights of those with bonded property as well. It is submitted that the developments affecting a debtor's estate that is not sequestrated either protects his or her continued occupation of the primary residence and/or they afford the debtor an opportunity while still in occupation to enter into a debt rearrangement with the creditor with a view to a time when for instance the debtor's financial position has improved in order for him or her to be able to pay the debt. Nevertheless, the measures developed in this instance were designed to prevent the debtor being rendered homeless and courts hearing such cases should seek solutions that protect the debtor as well as the interests of the creditor.

Against the backdrop of Part 1 of this article, the applicability of and possible protection offered by the PIE Act to insolvents facing eviction from their homesteads following sequestration of their estates have been considered in Part 2. The PIE Act is of general application and to some extent it gives effect to the constitutional imperatives in section 26 of the Constitution by making it compulsory in the case of an eviction application for the applicant owner or person in charge of the occupied property to follow a prescribed process to make an application to court to apply for eviction. ${ }^{153}$

148 See heading 4 in Part 1 of this article.

149 [2020] JOL 46613 (FS).

150 See heading 3 and 4 in Part 1 of this article.

15124 of 1936.

152 See heading 3 in Part 1 of this article.

153 See heading 4 in Part 1 of this article. 
This Act provides statutory defences that an unlawful occupant may raise in an attempt to remain in occupation of his or her house, the ultimate aim being to prevent the debtor from being rendered homeless. The South African legislature decided to apply the protective measures to the "primary residence" of the debtor; this resort is commendable since the notion of a family or matrimonial home may be too restrictive and perhaps militates against basic rights like gender equality.

In this article, the applicability of the PIE Act to protecting the occupancy of insolvents in certain circumstances was considered against the backdrop of pertinent aspects of insolvency law. It is clear that the PIE Act has application in relevant situations after sequestration as well; the insolvent who occupies his or her (former) house unlawfully may rely on the PIE Act with a view to not being evicted under certain conditions and depending on the facts of the case - these being mainly the personal circumstances of the insolvent and his or her dependants. ${ }^{154}$ The insolvent's claims are nevertheless pitted against the body of creditors. At the time of opposing an eviction order, the court hearing the sequestration application must amongst other reasons consider if there is an advantage to creditors before granting the order. Insolvency law dictates that the estate property ultimately vests in the trustee; he or she has a statutory duty to realise such assets to the benefit of the creditors in a relatively short prescribed time period. In many instances of consumer insolvency, the primary residence is in fact the main asset in the estate to be used to satisfy the creditors.

A number of court cases have considered the application of the PIE Act in an insolvency context. ${ }^{155}$ It is clear from these cases that the PIE Act applies in a sequestration context as well. The theme of the article was inspired by these judgments as referred to under heading 1 and further discussed under heading 4 in Part 1 of this article. In Body Corporate of Redberry Park $v$ Sukude $\mathrm{NO}^{156}$ (an application for compulsory sequestration), the court found, among other determinations, that the applicant had not established that there would be advantage to creditors when the debtor's property was sold in execution; it seemed to the court that the application for sequestration was motivated by the wish to circumvent the provisions of the PIE Act (with reference to the eviction of persons from the dwelling unit) and thereby to secure an advantage over the bond holder.

In another more pertinent judgment, Botha NO $v$ Kies, ${ }^{157}$ the court accepted that the protective measures of the PIE Act may be to the avail of an insolvent debtor faced with an eviction order by the trustee under applicable circumstances.

Lastly, there is the judgment in Mayekiso $v$ Patel NO, ${ }^{158}$ where the court considered various aspects of the PIE Act that may be relevant in a sequestration situation. In this case, among other defences, the insolvents

\footnotetext{
See heading 4 and 5 in Part 1 of this article.

155 See heading 5 in Part 1 of this article.

156 Supra.

157 Supra.

158 Supra.
} 
relied on those provided in the PIE Act in an attempt to extend their occupation of the family homestead.

It is clear that the PIE Act may provide some relief for an insolvent debtor regarding continued occupation of his or her former home but the question is whether the relief is adequate since the PIE Act was not designed in the first place with formal insolvency in mind. It is also telling that to date no insolvent who has used the PIE defences has succeeded, but the option remains available. ${ }^{159}$

In summary, the following aspects of the PIE Act must be considered when applying it in an insolvent situation - that is, when the estate of an insolvent has been sequestrated:

- The granting of a sequestration order that vests the insolvent estate assets or property (including the primary residence of the insolvent) in the trustee and divests the insolvent of his or her ownership is not currently subject to the same judicial oversight as is applicable in a case of a request to attach the primary residence and to declare it specially executable. ${ }^{160}$

- After sequestration and where the insolvent still occupies his or her house or land or another building or structure for dwelling or shelter purposes, the PIE Act is in principle applicable where the occupancy of the insolvent amounts to unlawful occupation of such a building or structure or land for residential purposes. ${ }^{161}$

- The trustee of the estate has the required locus standi to bring the application and will qualify as owner and/or as the person in charge of such property. ${ }^{162}$

- It is submitted that it is not clear on a reading of the Insolvency Act and the PIE Act whether or not sequestration per se causes the continued occupation of the insolvent after sequestration to be unlawful, but a case can be argued that the trustee, once appointed, could grant explicit or tacit permission to the insolvent to remain in occupation. From a practical point of view, and for the sake of certainty, it is submitted that the trustee has the authority to give notice to the insolvent to vacate the premises within a reasonable time. ${ }^{163}$ If the insolvent fails to vacate, then the trustee can bring the eviction application in terms of the PIE Act. The purpose of the notice will be to ensure that the insolvent's occupancy is or has become unlawful in order to bring the matter under the jurisdiction of the PIE Act and to avoid evidentiary issues.

- In practice, the trustee sometimes specifically agrees that the insolvent may remain in the premises on condition that he or she pays a kind of rental for the continued use of the property to the estate. The benefit of such an arrangement may be that the property earns income during the phase after sequestration and before it has been sold as directed by the creditors, but it may create additional problems in getting the insolvent

159 See heading 6 of this article.

160 See heading 3 in Part 1 of this article.

161 See heading 6 and 7 of this article.

162 Ibid.

163 See heading 6 and 7 of this article and see Starbuck NO v Halim supra. 
to vacate should it become necessary to so do. Once again, the trustee will have to ensure that the occupation is unlawful before attempting to bring an application for eviction. ${ }^{164}$

- It may seem odd that the insolvent who has been the registered owner of the property may rent the property from the trustee but it must be noted that the insolvent is divested of his or her property upon sequestration and that he or she in principle needs permission to occupy the property.

- Usually, the residence of the insolvent is thought to be the only property that is used as a dwelling or shelter for residential purposes but an insolvent may vacate the primary residence either before or after sequestration and move into another property - for instance, his flat or an apartment or even a movable structure such as a caravan, a boat or a shipping container. A movable structure used for such residential purposes could be located on land that forms part of the estate or on land belonging to someone else. It is submitted that the PIE Act will apply if all the requirements are met. It is clear that even such movables can be used for residential purposes as envisaged by the PIE Act.

- An interesting question may arise with regard to a movable asset, such as a caravan, that is used for residential purposes. In view of section 19 of the Insolvency Act, the sheriff has a duty to make an inventory of all movable estate property and to attach it and take possession of it. ${ }^{165}$ It seems that, in such a case, section 19 may become subject to the PIE Act. It must be noted that if the insolvent uses his or her caravan as a residence owing to financial problems, the caravan may be parked on land that the insolvent owned (now vesting in the insolvent estate) or the insolvent for instance may rent a parking spot at a caravan park. In the last-mentioned instance, occupation of the land may be legal but after the caravan has been claimed from the insolvent, occupation of the caravan as such may be deemed illegal.

- Where the property used for residential purposes is sold in terms of the resolution of creditors and if the trustee has not evicted the insolvent, it becomes the burden of the new owner to do so. Hence, it is advantageous for the creditors to see to it that the property is sold without the insolvent and/or family members still occupying the premises. ${ }^{166}$

- When the court ultimately has to decide on the granting of an eviction order, it will have to consider the relevant factors that should be considered in terms of the PIE Act. In this regard, the approaches developed by the courts following the Jaftha judgment may be of use. ${ }^{167}$

- It must be noted that section 4(7) of the PIE Act mentions that the defences that may be raised by the unlawful occupant will not apply if the property is sold in execution on behest of a mortgagee. A sale following a sequestration order is not a sale in execution and the

\footnotetext{
164 See heading 4 in Part 1 of this article and heading 6 and 7 above.

165 See heading 4 in Part 1 of this article and heading 6 above.

166 See ABSA Bank v Murray supra under heading 6.2 of this article.

167 See heading 3 in Part 1 of this article.
} 
exception in section 4(7) will thus not affect the application of section $4(7)$ in full. ${ }^{168}$

- Where a court decides not to evict an insolvent, due attention must be paid to the duration of the continued occupation since it remains important to wind up the insolvent estate within a reasonable time. The impact of the concursus creditorum therefore must be considered. Even so, the court must set a reasonable period for the insolvent to vacate the premises. This in itself may provide some relief for the insolvent since it provides time to find other accommodation. ${ }^{169}$

- As discussed above, there are a number of aspects that must be considered and interpreted when applying the PIE Act - especially in an insolvency matter. The PIE Act was clearly not written with the Insolvency Act and other legislation, such as the Deeds Registry Act, in mind, but it remains the task of the courts to give effect to it. It is a "strong-arm" Act in that it basically trumps other laws in relation to eviction; when applied in insolvency matters together with the aims of the PIE Act, it must be read in conjunction with its basic rights as genesis.

- It is clear that in the absence of a special insolvency dispensation to deal with the protection of the family home in South African insolvency law, the PIE Act at least offers an interim solution to vulnerable insolvents but it seems that the chances are not good for a successful attempt to remain in occupation. Since the PIE Act was not designed to cater for insolvents, its provisions need interpretation (sometimes liberal), to extend the relief to insolvents. It is submitted that an insolvency-specific model, taking all policy considerations into account, is the preferable option in the long run.

- It is clear that further consideration is required of the treatment of attachments of, and evictions from, a movable asset used for residential purposes under similar circumstances.

- In some instances, a person who is insolvent may occupy the premises of a company (or a trust) that may become insolvent. The insolvent may have the use of such property while exerting control over the company. If the company is liquidated, for instance, it seems clear that the liquidator of such company will have locus standi to apply for the eviction of an unlawful occupier. Sometimes such occupier may him- or herself be an insolvent whose personal estate has also been sequestrated, but he or she in fact uses the company or perhaps a trust as a vehicle to be vested with ownership of the house. ${ }^{170}$

- In a comparison, the protection offered by the PIE Act is more in line with the position in England than that in the USA. ${ }^{171}$ Should this matter be addressed in future by the legislature, policy considerations should be considered in working out which approach to follow in local circumstances.

168 See heading 4 in Part 1 of this article and heading 6 above.

169 See heading 6 of this article and Brodie $v$ Kgomasang supra.

170 See heading 6.1 of this article and Van der Merwe NO v Moodliar NO supra.

171 See heading 2 in Part 1 of this article. 
It is submitted that, in the absence of an insolvency-specific family home or primary residence dispensation, the PIE Act offers some protection to insolvent unlawful occupiers of their erstwhile family homes, but a number of vexing questions exist. Therefore it is submitted that such provisions should become part of insolvency law through legislative intervention with a view to establishing protective measures that address issues pertaining to insolvency and that provide certainty about adequate protection regarding the insolvent's right to housing. 